UDC 811.133.1'42:82-312.6(043.3)

DOI https://doi.org/10.26661/2414-1135-2020-80-2-6

\title{
CONCEPT BELLICOSITY IN COMMUNICATION AND CULTURE OF MODERN FRENCH (BASED ON THE ARTWORK OF AMELIE NOTHOMB)
}

\author{
Myronova N. V. \\ Candidate of Philology, \\ Senior Lecturer at the Department of Roman and Modern Greek Philology and the Translation \\ Kyiv National Linguistic University \\ Velyka Vasylkivska str., 73, Kyiv, Ukraine \\ orcid.org/0000-0002-9273-3863 \\ natalia.myronova@knlu.edu.ua
}

Key words: semantic structure of the concept, text concept, conceptual model, linguoculture, modern French prose.
This paper is a study of ethnocultural specificity of the linguocultural concept of BELLICISME in French communication. The theoretical basis of research is a complex of scientific works of cognitive-communicative orientation, in particular the sphere of lingual conceptology with the focus on the delineation of conceptual, figurative and valuable information in the structure of the concept, including the concept of the text, discourse, works on the theory of verbal poetic image and the theory of conceptual metaphor. Understanding of theoretical sources in philosophy, anthropology, culturology, archeology, religion, history, linguistic concepts and genderology in relation to the concept of bellicosity contributed to its definition as a multidimensional mental entity structured by the conceptual and figurative components and reinterpreted in the artistic discourse of the modern French language. The applied research complex methodology which includes specific linguistic methods (such as hypothetical-deductive, discursive, communicative and pragmatic), techniques involving linguocognitive method (techniques of framing, cognitive semantic analysis) helped solve the research problem and to achieve scientific objectives, namely: based on logical and conceptual principles and lexicographic sources, to define the structure of the concept of BELLICISME and identify its nucleus and periphery, as well as the means of its expression, that occur in the French language at the level of words, word-combinations, sentences, text, to construct its model on the material of the modern French language and in the author's individual conceptual sphere on the material of the literary texts by A. Nothomb, to explore the linguocultural specificity of the realization of the concept of BELLICISME in the contemporary French prose. The practical significance of the results is to broaden the theoretical and methodological basis of the concepts study in the linguocultural aspect. We can contribute the results and conclusions of work to the contemporary Romance linguistics, namely, to cognitive linguistics, the linguistics of concepts, in particular, artistic, thanks to the deepening of ideas about the conceptualization of bellicosity in contemporary French prose, reconstruction of the concept of BELLICISME and determination of the means of its verbalization in modern French and the study of the linguocultural specificity of its realization. 


\title{
КОНЦЕПТ ВОЙОВНИЧІСТЬ У СУЧАСНІЙ ФРАНЦУЗЬКІЙ ЛІНГВОКУЛЬТУРІ (НА МАТЕРІАЛІ ТВОРЧОСТІ АМЕЛІ НОТОМБ)
}

\author{
Миронова Н. В. \\ кандидат філологічних наук, \\ дочент кафедри романської і новогрещької філології і перекладу \\ Київський національний лінгвістичний університет \\ вул. Велика Васильківська, 73, Київ, Украӥна \\ orcid.org/0000-0002-9273-3863 \\ natalia.myronova@knlu.edu.ua
}

\author{
Ключові слова: семантична \\ структура концепту, \\ текстові кониепти, \\ концептуальна модель, \\ лінгвокультура, сучасна \\ франиузька проза.
}

Статтю присвячено дослідженню етнокультурної специфіки лінгвокультурного концепту BELLICISME у комунікативному просторі Франції. Теоретичне підгрунтя роботи становить комплекс наукових праць когнітивно-комунікативного спрямування, зокрема з лінгвоконцептології 3 акцентом на розмежування поняттєвої, образної та ціннісної інформації у структурі концепту, включаючи концептологію тексту, дискурсу, робіт 3 теорії словесного поетичного образу, з теорії концептуальної метафори. Критичне осмислення теоретичних джерел 3 філософії, антропології, культурології, археології, релігієзнавства, історії, лінгвоконцептології стосовно концепту «войовничість» сприяло його визначенню як багатовимірного ментального утворення, що структурується поняттєвим i образно-ціннісним компонентами, і піддається переосмисленню в художньому дискурсі сучасної французької мови. Застосована комплексна методика дослідження, що включає такі спеціальні лінгвістичні (гіпотетико-дедуктивний, дискурсивний, комунікативно-прагматичний) методи із залученням лінгвокогнітивного методу (методики фреймового, семантико-когнітивного аналізу), дозволила розв'язати поставлені дослідницькі завдання і досягти наукової мети, а саме: за логікопоняттєвим принципом із залученнямлексикографічнихджерел визначити структуру концепту BELLICISME з виділенням його ядра та периферії та засоби його вираження, репрезентація яких у французькій лінгвокультурі відбувається на рівні слів, словосполучень, речень, тексту, і побудувати його модель на матеріалі сучасної французької мови та в індивідуальноавторській концептосфері на матеріалі художніх текстів А. Нотомб, дослідити лінгвокультурну специфіку реалізації концепту BELLICISME у сучасній французькій прозі. Практичне значення одержаних результатів полягає у розширенні теоретичних і методологічних основ дослідження концептів у лінгвокультурному аспекті, у внеску результатів і висновків роботи у сучасне романське мовознавство, а саме у когнітивну лінгвістику, лінгвоконцептологію, зокрема художню, завдяки поглибленню уявлень про концептуалізацію войовничості у сучасній французькій прозі, реконструкції концепту BELLICISME та визначенню засобів його вербалізації у сучасній французькій мові, дослідженню лінгвокультурної специфіки його реалізації.
Introduction. Bellicosity accompanies human communication and is translated in it through a complex interweaving of intentional, cognitive and moral aspects, marking the conflict between norm, morality and peacefulness as one of the fundamental existential values.

Despite a significant number of studies of bellicosity in philosophy [1], anthropology [2], cultural studies [3], archeology [4], religious studies [5], his- tory [6], there are gaps in the study of this concept in linguistics. The study of bellicosity as a fragment of the Anglo-Saxon model of the world on the material of the Old English heroic poetry of Y.S. Hrihorieva might be the only scientific work on this issue.

The concept of bellicosity is of a high social significance, and nowadays this phenomenon plays a specific role in the intercultural communication. 
Understanding of the problem of semantics of literary text from the cognitive and cultural point of view allows to penetrate deeper into the hidden meaning of the literary work, to adequately understand the writer's attitudes as a carrier of a certain linguoculture, which is an integral part of the linguistic personality of the author.

The relevance of the topic consists in the growing of the research interest in the study of processes and mechanisms of conceptualization of notions, their volume, meaning, relation to language and speech. Modern linguistics is characterized by an increased interest of scientists in the development of anthropocentric paradigm in the study of language and thought processes, operated by a person in the course of his practical and cognitive activities.

The following questions remain insufficiently studied: the place of the concept of BELLICISME in the French linguistic consciousness, the characteristics of lexemes verbalizing it, as well as the mechanisms of its objectification.

The relevance of the study also consists in the fact that the analysis of lexemes that nominate the concept of BELLICISME in the French language is carried out in line with linguoculturology, and, to our knowledge, the cognitive and cultural aspects of bellicosity as a linguocultural concept have not been studied yet.

Anthropocentrism as one of the priority directions in the development of the modern text linguistics has caused the interest of scientists to study the language in close relationship with the person, his consciousness, reasoning and culture $[7 ; 8 ; 9]$.

The scientific basis of the study was the work of native and foreign scientists in the field of cognitive semantics and linguistic conceptology, linguoculturology, theory of frames, theory of conceptual metaphor, theory of language assessment, theory of prototypes.

Scientific researches of the last decades are characterized by close attention of researchers to studying the linguistic means of representation of concepts: in texts $[10 ; 11]$ and in different types of discourse $[12 ; 13 ; 14 ; 15]$, dividing them into typical $[16 ; 17]$ and specific $[18 ; 19]$.

The objective of the study is to establish the ethnocultural specificity of the linguocultural concept of BELLICISME in the French-speaking communicative space.

Methods. The theoretical and methodological basis of the study determines the use of the following methods: traditional general scientific (synthesis, induction, deduction, hypothesis, concretization, generalization, etc.), specifically scientific theoretical (hypothetical, historical, logical), empirical (observation, analysis of experience, generalization, description of results, comparisons, calculations) and specific, namely linguistic methods, in particular: hypothetic deductive, discursive, communicative-pragmatic.
The use of the descriptive method is reduced to the basic and detailed description of the object under study. The method of observation consists in the allocation of certain features of linguistic categories (grammatical forms, groups of words), in their characteristics from a grammatical and stylistic point of view (grammatical, stylistic) and is translated in the observations of the language, in the analysis of literary works in relation to their style, vocabulary, visual means. The use of the hypothetic deductive method in the analysis of literary text allowed to collect the actual language material for the study, which was generalized by induction. Communicative pragmatic method is aimed at studying the communicative features of the literary text.

Accomplishment of the research tasks and achievement of the research objectives made it necessary to apply linguistic and cognitive method (methods of frames, semantic cognitive analysis to build a model of the concept BELLICISME, the analysis of dictionary definitions with the elements of the procedures of semantic deployment and paraphrasing, notion and component analysis - for inventory, structural semantic classification of the means of verbalization of the concept BELLICISME, elements of the quantitative analysis of the received language data to justify the selection of the concept BELLICISME), etymological analysis, to establish the etymon of the concept of BELLICISME, contextual analysis is to identify discursive realizations of the means of verbalization of the concept BELLICISME, the method of continuous sampling and contextual interpretative analysis to study gender specifics of actualization of the concept BELLICISME in modern French prose.

The study of verbalization and text actualization of the concept of BELLICISME was carried out according to the following algorithm.

The first stage is reflexive, it combines inductive and deductive methods to establish trends in the evolution of scientific views on the phenomenon of bellicosity in humanitarian studies coming out to the cognitive discursive paradigm of linguistics. Generalization of theoretical and methodological achievements concerning the model of the world contributed to the definition of the concept of BELLICISME as verbalized fragment of the French-speaking and individual author's conceptosphere, constructed in modern French prose.

The second stage is focused on the description of verbal representation of the concept of BELLICISME. At this stage, we could identify its layered structure. Thanks to the method of continuous sampling, from the French lexicographic sources we chose lexemes that form its nominative space: lexeme bellicisme, its synonyms, related and single-root words. The connection between language and thinking makes it possible to study the semantic content 
of concepts by analyzing the semantics of language units. So, on the basis of etymological, component analysis and the analysis of dictionary definitions of nominees of notion, it was possible to allocate semantic components which form the apprehension of the notion of BELLICISME by French native speakers. To model the reference content of this concept, a conceptual model was built.

The next step of semantic analysis, aimed at identifying associative links between the basic features of the concept of BELLICISME, was carried out through the construction of synonymic rows [20].

Interpretative third phase of exploration was carried out in the framework of cognitive approach, in particular using the methods and techniques of semantic, linguo-stylistics and conceptual analyses aimed at the mental representation of the specified concept in the study of literary works through the elucidation of the basic schemes of the conceptualization of bellicosity in the works of A. Nothomb. For this purpose, the method of analysis of text concepts of fictional texts [10], as well as the method of frame analysis [21;22], was chosen, which allowed to establish productive schemes of conceptualization of BELLICISME and simulate its figurative space. At this stage, we investigated the nominative field of the concept of BELLICISME in the textual plane of literary works and built its conceptual model in the individual author's consciousness of A. Nothomb.

The purpose of the fourth stage was to determine the specifics of actualization of BELLICISME in the individual author's concept sphere of A. Nothomb. For this purpose, we applied the method of analysis of gender stereotypes, which consisted in deep cognitive processing of texts and the study of the manifestation of gender characteristics of speech of characters, women and men, in the form of themes, plots, images, symbols, metaphors, etc.

As a field of speech representation of the concept BELLICISME we selected the discourse presented by the contemporary novels of the French author Amélie Nothomb. Artistic discourse, which is a set of literary texts, the result of communication and verbalized mental and speech activity of the writer, is one of the public, deeply informative ways of transmitting any information.

We have revealed that the representation of the concept of BELLICISME in the French language through the prism of linguoculturology is complex and heterogeneous. Therefore, it is desirable to take into account multiple methods while making research in this area. The method of continuous sampling we define as one of the main for the selection and classification of language material representing the concept BELLICISME in the French language and in the novels of A. Nothomb. The results obtained in the process of semantic cognitive analysis, the analysis of dictionary definitions with the elements of the procedures of semantic deployment and paraphrasing, component analysis, elements of the quantitative analysis of linguistic data, etymological analysis, contextual analysis helped to understand how the concept BELLICISME is reflected in the language. The use of hypothetical deductive method in the study of literary text allowed to collect the actual speech material of the study, which was generalized by induction.

The method of contextual analysis, which explores not only the semantic meaning of a single lexical unit, but also pragmatic, that is, its integral relationship with the communicative situation in combination with the methodology of semantic and cognitive analysis of text concepts of fiction allowed to construct a conceptual model of the concept of BELLICISME in the individual author's concept sphere of A. Nothomb.

The method of continuous sampling and contextual interpretative method allowed to study the linguocultural specificity of the BELLICISME concept actualization in modern French prose.

The research data includes 1150 units that verbalize the concept of BELLICISME in French. The analysis of the definitions of the selected lexical and phraseological units was carried out according to the authoritative lexicographic sources of the publishing house Larousse, Maxidico, Bordas, etc. The material of the study is 3350 situational contexts containing the concept of BELLICISME and selected by a continuous sampling from the texts of modern novels by A. Nothomb ("Attentat", "Les Catilinaires", "Les Combustibles", "Hygiène de l'assassin", "Métaphysique des tubes", "Mercure", "Le Sabotage amoureux", "Péplum", "Le Robert des noms propres", "Stupeur et tremblements"), the total volume of which is 1675 pages.

Results and Discussion. Research of authoritative lexicographical sources of the French language allowed to determine the structure of the concept in the language model of the world of its speakers with the allocation of its nucleus, near periphery and distant periphery. We described all nominative units that verbalize concept BELLICISME in the French language, distinguished the key words-representatives: bellicisme, caractère belliqueux, bellicosité, submitted filed synonymy and etymology of the concept BELLICISME, presented lexico-semantic and lexico-phraseological field of the studied concept, constructed the conceptual model of the concept BELLICISME in the French-speaking model of the world.

A comparison of the meanings of the keywords-representatives allows to draw conclusions about the generic meaning of the concept BELLICISME that can be described as:

- doctrine, providing the military settlement of international problems;

- tendency of encouraging the use of force when settling conflicts, mainly in international relations; 
- a person who is set up for war;

- a person who is in favor of war and is looking for ways and means to cause or contribute to it;

- a person who openly demonstrates a tendency to contention and controversy;

- an aggressive, warlike, quarrelsome, fighting person;

- a strong, hard, violent, impatient person.

It is, in fact, individual values, not meanings because they indicate different denotations of reality.

Summarizing everything mentioned above, we come to conclusion that bellicosity is:

- a desire, an inclination to fight;

- orientation on the outbreak of war;

- the property to wage an irreconcilable struggle with someone, something;

- property to express a willingness to quarrel, argue, fight.

The set of linguistic and extralinguistic knowledge of society about bellicosity is the only conceptual basis for identifying patterns of categorization, conceptualization and verbalization of this fragment in the French-speaking model of the world.

Semantic field of bellicosity is a constructive association of language units, which objectify concept BELLICISME. The composition of the studied field is determined by the logical conceptual principle with the application of lexicographical sources. It is established that in the French-speaking model of the world, this concept is objectified not only by the lexeme bellicisme, but also by a number of synonyms, related and single-root words, which include the following lexemes: belliciste, belliqueux. Lexemes of the semantic field of the concept of BELLICISME form a certain model. In its structure we can distinguish the nucleus, near and distant periphery.

The concept of BELLICISME is characterized by the main semantic and additional features presented in the distinctive features of lexemes-constituents of the semantic field of the concept of BELLICISME. Each feature is identified by a number of thematically related lexical units. Based on the set of semantic components, we derive a cognitive characteristic of the semantic field of the concept of BELLICISME.

The complex of semantic features of the concept of BELLICISME and their words-indicators became the basis for the construction of the original hypothetical model of the conceptual space of bellicosity in the French-speaking model of the world.

Synonyms of the key word, verbalizing the concept under study, provided an opportunity to identify its differential features by correlating the lexemes belonging to the same synonymic rows.

We selected 271 lexemes, that form 8 synonymic and 7 antonymic rows. This allowed to identify the semantic components of the concept BELLICISME: BELLIQUEUX, GUERRE, PEUR, CRIME, PUNITION, VICTIME, VICTOIRE.
The construction of lexico-phraseological field of its keyword significantly expanded the idea of the content and structure of the concept under study.

As a result of the study of the lexico-phraseological means of desobjectivation of the concept BELLICISME we distinguished three groups, designating the next fragments of the conceptual space of bellicosity: actional bellicosity (47,54\%), active bellicosity $(31,15 \%)$, passive bellicosity $(21,31 \%)$.

Within each of these fragments, lexico-phraseological groups are distinguished, forming subgroups, on the basis of coincidence in some units of signs, specifying the nature of the action.

We revealed that actional militancy is the most widespread in the French language, where we distinguish a subgroup of lexical phraseological means, that:

- nominate bellicosity in a certain state or deployment of action: état de guerre, sur la pied de guerre, à la guerre comme à la guerre, la guerre nourrit la guerre;

- denote the actual bellicosity actions: aller / marcher / partir en (à la) guerre contre qn, aller faire la guerre au pain, rendre guerre pour guerre;

- denote the cessation of hostilities: enterrer la hache de guerre, fermer les portes de la guerre, chanter victoire, obtenir les honneurs de la guerre.

The conceptual model of the concept of BELLICISME in the French-language model of the world (according to the results of lexicographical analysis) consists of seven semantic components.

We revealed that the nucleus of the studied concept includes semantic information components with greater sensory and visual concreteness, the primary images BELLICISME/BELLIQUEUX/BELLICOSITÉ. The near periphery is represented by an additional set of nominations that objectify each of the primary features. Thus, the near periphery consists of the concepts GUERRE, PEUR, distant - CRIME, PUNITION, VICTIME, VICTOIRE.

The features of the conceptual model of the concept of BELLICISME include the conceptual opposition of CRIME - PUNITION, which is a component of the distant periphery of the concept of BELLICISME.

So, the conceptual model of the concept BELLICISME in the francophone model of the world consists of a nucleus - BELLICISME, the near - GUERRE, PEUR, and the distant periphery - CRIME, PUNITION, VICTIME, VICTOIRE.

On the material of the literary works of A. Nothomb we detailized and specified conceptual model of the concept BELLICISME by analyzing the text concepts of the author's artwork.

The conceptual model of the world is represented by the linguistic picture of the world and has certain features. In addition to the universal picture of the world, common to all people, we can distinguish: national 
linguistic picture of the world, representing the worldview of the ethnic group, its traditions and cultural norms, its worldview of the relationship between a man and the world; individual linguistic picture of the world, which verbalizes the knowledge and experience of a man about the world on the basis of its personal properties, the inner world, psychological and cognitive processes; gender-specific linguistic picture of the world, which reflects the worldview of people according to a certain gender. Introducing the cognitive space of an individual, all of these linguistic pictures of the world interact and influence one another.

The analysis of the artwork of A. Nothomb, namely text concepts that verbalize the concept BELLICISME in modern French prose, helped to refine and concretize this concept, gave the possibility to construct a conceptual model of bellicosity in the author's individual consciousness of the author.

In total, all the works under study have all semantic components. Their representatives are both direct and indirect nominees. The representation of BELLICISME in a literary text is wider than in a lexicographical one due to the indirect realization of the concept.

So, the conceptual model of the concept BELLICISME in the author's individual consciousness of A. Nothomb (according to the analysis of her artwork) consists of the nucleus (BELLICISME), near periphery (GUERRE, PEUR, CRIME, PUNITION, VICTIME, VICTOIRE) and distant periphery (VIE, JEU DIEU, AMOUR).

The image of love is closely related to bellicosity. The concept of AMOUR in the conceptual sphere of the male character unfolds as follows:

- a man is ready to do anything to get what he wants from a woman, that is, AMOUR - POUVOIR;

- AMOUR for a man is MALADIE, which makes him dependent on the object of love;

- indeed, a person in love cannot help but hurt the object of love (AMOUR - SOURCE DE SOUFFRANCE).

The concept of AMOUR in the conceptual sphere of the female character is represented by the conceptual model of AMOUR - LUTTE INTERNE, which consists in struggle of respect and aversion to a man, aversion to the body and love for the spiritual world of the partner, gratitude and hate.

Analyzing the concept of AMOUR from the point of view of the relation of platonic and corporeal, we established that the male character mixes the ideas of platonic and corporeal love. That is, the conceptual scheme of AMOUR PARENTAL is destroyed: AMOUR - STORGE is mixed with AMOUR EROS. So, the nucleus of the concept of AMOUR PARENTAL shifts from a sense of care and concern for your child to the sexual relations of a young girl with an elderly man.
Having studied the conceptual model of AMOUR LIBERTE, we established that in the perception of a man there is a closed model of AMOUR - PROPRIÉTÉ, in the perception of a women there is a model of AMOUR - LIBERTÉ. We determined that the dominant models for women are AMOUR LIBERTÉ, AMOUR - MYSTĖRE and AMOUR INTÉRÊT.

So, we came to the conclusion that the concept of AMOUR is contained in various conceptual models of love, that function in the conceptual sphere of heroes, and which are associated with the dominant type of love in their minds. This is more evident in such conceptual models as: AMOUR - LIBERTE, AMOUR - PROPRIÉTÉ and AMOUR - MALADIE, AMOUR-LUTTE INTERNE.

Conclusions. The study of the concept of BELLICISME in modern French linguoculture established its ethnocultural specificity, which determines the relationship of cultural, national and linguistic factors in the process of understanding the bellicosity relations. In the article the verbalized linguocultural concept of BELLICISME was studied within the limits of the francophone generally accepted (according to the results of lexicographical analysis) and individual author's (according to the results of the analysis of A. Nothomb's literary works) pictures of the world.

The studied material helped to discover the features of conceptualization and categorization of bellicosity through the allocation of cognitive meanings of the concept, which complement the basic lexical meaning of the name of the concept. This aspect could be taken into account when elaborating dictionaries and translating. The article reveals the features of the categorization of bellicosity on the example of role differentiation of participants of bellicosity relations.

The results of the research open up prospects for further scientific research in the field of gender and cognitive linguistics. It is expedient to study the representation of the concept of BELLICISME in the comparative aspect on the material of several languages and in other genres of prose discourse.

\section{BIBLIOGRAPHY}

1. Джохадзе И.Д. Прагматизм и война. История философии. Москва, 2015. Т. 20. № 1. C. 193-214. URL: https://elibrary.ru/item. asp?id $=25868452$.

2. Шевченко Е.Б. Воинственность женщин в среде ранних кочевников (по данным письменных свидетельств). Stratum plus: Archaeology and Cultural Anthropology. Кишинев, 2018. № 3. C. 165-179. URL: https://elibrary.ru/item. asp? $\mathrm{id}=35300653$ (дата звернення: 09.09.2020).

3. Мутиева О.С. К вопросу об истоках женской воинственности у народов Дагестана. Современные тенденциии развития науки и техноло- 
гий. Белгород, 2015. № 7-4. C. 112-114. URL: https://elibrary.ru/item.asp?id=25024943 (дата звернення: 09.09.2020).

4. Гуляев В.И. Роль войны и военного дела в развитии древних и средневековых обществ. Краткие сообщения института археологии. Москва, 2013. Вып. 231. С. 3-9. URL: https:// books.google.com.ua/books? id=AmmPCgAA QBAJ\&pg=PA4\&lpg=PA4\&dq=воинственность+в+археологіï\&source (дата звернення: 09.09.2020).

5. Троицкий А.А. Женщина и война. Мужское и женское: сотрудничество и конфронтация : сб. науч. тр. Междунар. науч. конф. Санкт-Петербург, 2016. C. 294-297. URL: https://elibrary. $\mathrm{ru} / \mathrm{item} . \mathrm{asp}$ ? $\mathrm{id}=27568394$ (дата звернення: 09.09.2020).

6. Кутищев А.В. Воинственность как культурно-ментальный феномен позднего феодализма. Universum: общественные науки. Москва, 2015. № 1-2 (12). С. 4. URL: https:// elibrary.ru/item.asp?id=22993761 (дата звернення: 09.09.2020).

7. Арутюнова Н.Д. Предисловие. Логический анализ языка: культурные кониепты. Москва : Наука, 1991. С. 3-4.

8. Арутюнова Н.Д. Язык и мир человека. Москва : Языки русской культуры, 1999. 896 с.

9. Караулов Ю.Н. Русский ассоциативный словарь как новый лингвистический источник и инструмент анализа языковой способности. Русский ассоциативный словарь. Москва : Помовский и партнеры, 1994-1996. С. 191-218.

10. Кагановська О.М. Текстові концепти художньої прози (на матеріалі французької романістики середини XX сторіччя) : монографія. Київ : Видавничий центр КНЛУ, 2002. 292 с.

11. Буць Ж.В. Текстовий концепт ЖІНОЧНІСТЬ у французьких соціально-побутових романах XIX-XX століть : лінгвокультурологічний і комунікативно-прагматичний аспекти : автореф. дис. ... канд. філол. наук : спец. 10.02.05. Київ, 2012. 20 с.

12. Косович О.В. Принципи мовної централізації (на прикладі французької мови). Серія Філологія : наук. вісн. Міжнар. гуманіт. ун-ту : зб. наук. пр. Вип 32 (2). Одеса, 2018. С. 57-60.

13. Косович О.В. Просторове варіювання полінаціональної мови як константа досліджень у романістиці. Серія Філологія : наук. вісн. Міжнар. гуманіт. ун-ту : зб. наук. пр. Вип 33. Т. 2. Одеса, 2018. С. 55-57.

14. Круковський В.I. Концепт, термін, дефініція і спеціалізований дискурс. Проблеми семантики, прагматики та когнітивної лінгвістики : зб. наук. пр. Вип. 24. Київ : Логос, 2013. C. $188-199$.
15. Круковський B.I. Концепти суб'єктивність/ об'єктивність, модалізація/модальність та засоби їх вираження в мові та мовленні: питання теорії (на матеріалі французької мови). Філологія. Педагогіка. Психологія : наук. вісн. каф. ЮНЕСКО КНЛУ. / Гол. ред. 3.О. Валюх. Вип. 35. Київ : Вид. центр КНЛУ, 2017. C. 166-188.

16. Воронова Т.А., Стернин И.А. Концепт «толерантность» в русском сознании. Языковая структура и сочиальная среда. Воронеж, 2000. C. 79-83.

17. Колесов В.В. Концептология : конспект лекций, читанных в сентябре-декабре 2010 года. Санкт-Петербург, 2012. 168 с.

18. Апресян Ю.Д. Избранные труды. Т. 2. Интегральное описание языка и системная лексикография. Москва : Языки русской культуры, $1995.767 \mathrm{c}$.

19. Шмелев А.Д. Русская языковая модель мира : материалы к словарю. Москва : Языки славянской культуры, 2002. 224 с.

20. Степанов Ю.С. Язык и метод. К современной философии языка. Москва : Языки русской культуры, 1998. 784 с.

21. Жаботинская С.А. Когнитивная лингвистика: принципы концептуального моделирования. Лінгвістичні студії. Вип. 2. Черкаси, 1997. C. 3-11.

22. Жаботинская С.А. Концептуальный анализ: типы фреймов. Вісник Черкаського університету. Серія «Філологічні науки». Вип. 11. Черкаси, 1999. С. 12-25.

\section{REFERENCES}

1. Dzhokhadze, I.D. (2015). Prahmatizm i voina [Pragmatism and war]. Istoriia filosofii. Moskva, Vol. 20, No 1, pp. 193-214. Retrieved from: https://elibrary.ru/item.asp?id=25868452.

2. Shevchenko, E.B. (2018). Voinstvennost zhenshchin $\mathrm{v}$ srede rannikh kochevnikov (po dannym pismennykh svidetelstv) [The militancy of women among the early nomads (according to written evidence)]. Stratum plus: Archaeology and Cultural Anthropology. Kishinev, No 3, pp. 165-179. Retrieved from: https://elibrary.ru/ item.asp? $\mathrm{id}=35300653$.

3. Mutiieva, O.S. (2015). K voprosu ob istokakh zhenskoi voinstvennosti u narodov Dahestana [On the question of the origins of female militancy among the peoples of Dagestan]. Sovremennyie tendentsii razvitiia nauki s tekhnolohii. Belhorod, No 7-4, pp. 112-114. Retrieved from: https://elibrary.ru/item.asp?id=25024943.

4. Huliaev. V.Y'. (2013). Rol voiny i voennoho dela $\mathrm{v}$ razvitii drevnikh i srednevekovykh obshchestv [The role of war and military affairs in 
the development of ancient and medieval societies]. Kratkie soobshcheniia instituta arkheolohii. Moskva, Vol. 231, pp. 3-9. Retrieved from: https://books.google.com.ua/books?id=Am$\mathrm{mPC}$ A A QBAJ \& p g=PA4 \& $1 \mathrm{pg}=\mathrm{PA} 4 \& \mathrm{~d}-$ $\mathrm{q}=$ воинственность + В + apхеологіï\&source.

5. Troitskii, A.A. (2016). Zhenshchina i voina. Muzhskoie i zhenskoie: sotrudichestvo i konfrontatsiia [Woman and War. Male and female: cooperation and confrontation]: sb. nauch. tr. Mezhdunar. nauch. konf. Sankt-Peterburh, pp. 294-297. Retrieved from: https://elibrary.ru/ item.asp?id=27568394.

6. Kutyshchev, A.V. (2015). Voinstvennost kak kulturno-mentalnyi fenomen pozdneho feodalizma [Militancy as a cultural and mental phenomenon of late feudalism]. Universum: obshchestvennyie nauki. Moskva, No 1-2 (12), p. 4. Retrieved from: https://elibrary.ru/item.asp?id=22993761.

7. Arutiunova, N.D. (1991). Predislovie [Preface]. Lohycheskii analiz yazyka : kulturnye kontsepty. Moskva: Nauka, pp. 3-4.

8. Arutiunova, N.D. (1999). Yazyk i mir cheloveka [Human language and world]. Moskva: Yazyki russkoi kultury. $896 \mathrm{p}$.

9. Karaulov, Yu.N. (1994-1996). Russkiy assotsiativnyi slovar kak novyi linhvisticheskii istochnik I instrument analiza yazykovoi sposobnosti [Russian associative dictionary as a new linguistic source and tool for analyzing language ability]. Russkiy assotsiativnyi slovar. Moskva: Pomovskii i partnery, pp. 191-218.

10. Kahanovska, O.M. (2002). Tekstovi kontsepty khudozhnoi prozy (na materiali frantsuzskoi romanistyky seredyny XX storichchia). [Concept texts of artistic prose (based on materials of French romance of the middle of the 20th century)]: monohrafiia. Kyiv: Vydavnychii tsentr KNLU.

11. Buts, Zh.V. (2012). Tekstovyi koncept ZHINOCHNIST u frantsuzkykh socialno-pobutovykh romanakh XIX-XX stolit: lingvokulturolohichnyi i komunikatyvno-pragmatychnyi aspekty [Textual concept of FEMININITY in French socially-whipped novels of the 19th-20th centuries: linguoculturological and communicative-pragmatic aspects]: avtoref. dys. ... kand. filol. nauk: spets. 10.02.05. Kyiv.

12. Kosovych, O.V. (2018). Prostorove variiuvannia polinatsionalnoi movy iak konstanta doslidzhen u romanistytsi [Principles of modern centralization (in French language)]. Seriia Filolohiia: nauk. visn. Mizhnar. humanit. un-tu : zb. nauk. pr. No 33, Vol 2. Odesa, pp. 55-57.
13. Kosovych, O.V. (2018). Pryntsypy movnii tsentralizatsii (na prykladi frantsuzkoi movy) [Spatial variation of the field of national language as a constant of research in novels]. Seriia Filolohiia : nauk. visn. Mizhnar. humanit. un-tu : zb. nauk. pr. No. 32 (2). Odesa, pp. 57-60.

14. Krukovskii, V.I. (2013). Kontsept, termin, definitsiia i spetsializovanyi dyskurs [Concept, term, definition and specialized discourse]. Problemy semantyky ta kohnityvnoi linhvistyky: zb. nauk. pr. No. 24. Kyiv: Lohos, pp. 188-199.

15. Krukovskii, V. I. (2017). Kontsepty obiektyvnist/subiektyvnist, modalizatsiia/modalnist ta zasoby ikh vyrazhennia $\mathrm{v}$ movi ta movlenni: pytannia teorii (na materiali frantsuzkoi movy) [Concepts of subjectivity/objectivity, modalization/modality and means of their expression in language and speech: questions of theory (on the material of the French language)]. Filolohiia. Pedahohika. Psykholohiia: nauk. visn. kaf. YUNESKO KNLU. No. 35. Kyiv: Vyd. Tsentr KNLU, pp. 166-188.

16. Voronova, T.A., Sternin Y'.A. (2000). Koncept "tolerantnost" v russkom soznanii [The concept of "tolerance" in Russian consciousness]. Yazykovaia struktura $i$ sotsyalnaya sreda. Voronezh, pp. $79-83$.

17. Kolesov, V.V. (2012). Konseptolohiia: konspekt lektsii, chitannykh v sentiabre-dekabre 2010 hoda [Conceptology: lecture notes given in September-December 2010]. Sankt-Peterburg.

18. Apresian, Yu.D. (1995). Yzbrannye Trudy. Intehralnoe opisanie yazyka i systemnaia leksikohrafiia [Selected Works. Integral description of the language and systemic lexicography]. T. 2. Moskva: Yazyki russkoi kultury.

19. Shmelev, A.D. (2002). Russkaia yazykovaiai model mira: materialy k slovariu [Russian language model of the world: materials for the dictionary]. Moskva: Yazyki slovianskoi kultury.

20. Stepanov, Yu.S. (1998). Yazyk i metod. K sovremennoi filosofii yazyka [Language and method. Towards a modern philosophy of language]. Moskva: Yazyki russkoi kultury.

21. Zhabotinskaia, S.A. (1997). Kohnitivnaia linhvistika: printsypy kontseptualnoho modelirovaniia [Cognitive linguistics: principles of conceptual modeling]. Linhvistychni studii. No. 2. Cherkasy, pp. 3-11.

22. Zhabotinskaia, S.A. (1999). Kontseptualnyi analiz: tipy freimov [Conceptual Analysis: Frame Types]. Visnyk Chernaskoho universytetu. Seriia "Filolohichni nauky". No. 11. Cherkasy, pp. 12-25. 